Forgotten Modernization, Building Bridges and Roads in Imperial Brazil: Engineers and Craftsmen in an Exporting Region in Minas Gerais (1850-1875)

\section{Modernização esquecida, construindo pontes e estradas no Brasil Imperial: engenheiros e artífices em uma região exportadora em Minas Gerais (1850-1875)}

\begin{abstract}
Resumo
Este artigo analisa a modernização da infraestrutura viária no terceiro quartel do século XIX na região da Mata mineira, com base no Banco de Dados dos Processos de Construção de Estradas e Pontes. Verifica-se que a região da Mata presenciou (I) a intensa circulação de engenheiros e, consequentemente, a junção de problemas técnicos e econômicos na edificação de pontes e estradas; (II) a fragilidade do sistema de patentes de 1830 na tentativa de construção e difusão de uma ponte pênsil no Brasil; (III) a existência de rotas internas que atendiam à circulação agropecuária mercantil. 0 artigo mostra as relações entre o mercado (setor de exportação e abastecedor de gêneros alimentícios), o Estado e os transportes.
\end{abstract}

\section{Abstract}

This article analyses the modernization of road infrastructure in the Zona da Mata mineira during the third quarter of the nineteenth century. The evidences gathered indicate: (1) an intense circulation of engineers and how their activities interwove technical and economic problems during the process of construction roads and bridges; (2) the weaknesses of the Brazilian patent system (1830) to stimulate the construction of suspension bridges; (3) the presence of internal routes that supported the circulation of agricultural and livestock goods. The article explores the relationship between State, market (export sector and non-export sector) and the transportation system.

\footnotetext{
Palavras-chave

região da Mata mineira, século XIX, modernização, economia, transportes

Keywords

Mata mineira region, nineteenth century, modernization, economy, transport
} 

partir da análise do Banco de Dados dos Processos de Construção de Estradas e de Pontes. 0 Banco de Dados apresenta extensa amplitude temporal e espacial, alcançando um expressivo volume documental, aproximadamente 24.000 documentos. 0 início do cotejamento das informações contidas nos processos ocorreu no ano de 2004 e prolongou-se até 2008 quando foi concluida a etapa de levantamento, catalogação e indexação. Posteriormente, em 2009, iniciou-se a etapa de codificação dos dados recolhidos e criação do Banco de Dados dos Processos de Construção de Estradas e Pontes. A referida base de dados é desenvolvida no Núcleo de Pesquisa em História Econômica e Demográfica do Centro de Desenvolvimento e Planejamento Regional da Universidade Federal de Minas Gerais (CEDEPLAR/UFMG) sob a coordenação do professor Marcelo Magalhães Godoy.

2

GODOY, Marcelo Magalhães. Intrépidos viajantes e a construção do espaço: uma proposta de regionalização para as Minas Gerais do século XIX. Texto para discussão n.109. Belo Horizonte: Cedeplar/UFMG, 1996. p.54-55. Para uma análise de outras propostas de regionalização da região da Mata mineira, ver: SARAIVA, Luiz Fernando. 0 Império das Minas Gerais: café e poder na zona da Mata mineira, 1853-1893. Tese (Doutorado em História Social). Programa de Pós-Graduação em História Social, Universidade Federal Fluminense, Niterói, 2008; CARRARA, Angelo Alves. Estruturas agrárias e capitalismo: contribuição para o estudo de ocupação do solo e de transformação na zona da Mata mineira (séculos XVIII e XIX). Núcleo de História Econômica e Demográfica,Serie Estudos n.2, Mariana: Universidade Federal de Ouro Preto, 1999. Sobre uma abordagem metodológica dos conceitos de região, regionalização e espaços econômicos, ver: CUNHA, Alexandre Mendes; SIMÕES, Rodrigo Ferreira; PAULA, João Antônio de. História econômica e regionalização: contribuição a um desafio teórico-metodológico. Estudos Econômicos, São Paulo, v.38, n.3, p.493-524, jul./set. 2008.

3

Em abril de 1856, a Companhia União e Indústria iniciou a construção da estrada. Obteve garantia de juros de $5 \%$ sobre o capital formado pela Companhia, de acordo com a lei provincial n.51, de 25 de setembro de 1854 . E, posteriormente, juros de 2\% concedido pelo Governo Imperial através do Decreto n. 1785 de 19 de março de 1856. A construção da estrada foi dividida em duas secções: 1. entre Petropólis e Pedro do Rio com extensão de 30 quilômetros; 2 . Ponte de Paraibuna a Juiz de Fora, totalizando cerca de 45 quilômetros. A estrada fora inaugurada em 1861. Em 1869, através do Decreto n. 2.325 de janeiro, a Companhia transferiu integralmente para a Estrada de Ferro D. Pedro II o transporte de cargas, que ficaria a partir de então centralizado em EntreRios. Cf. SILVA, Moacir. Geografia dos transportes no Brasil. Rio de Janeiro: Instituto Brasileiro de Geografia e Estatística, 1949. p.83 e p.88-90; Idem. Kilometro zero. Caminhos antigos - estradas modernas. Rio de Janeiro: 1934. p.104-106.

4

GENOVEZ, Patrícia Falco. Barões numa perspectiva reticular: análise de redes sociais, poder e nobreza na Zona da Mata mineira no segundo Reinado. Tempo.
Introdução

Neste estudo, pretende-se analisar a construção da infraestrutura viária edificada na região da Mata mineira durante o terceiro quartel do século XIX. Para tanto, utilizam-se os dados contidos no Banco de Dados dos Processos de Construção de Estradas e Pontes da província de Minas Gerais. ${ }^{1}$

Assim, baseando-se na divisão territorial de Minas Gerais, em dezoito regiões, optou-se pela região da Mata para tal análise. ${ }^{2}$

\section{Figura 1 - Regionalização da província de Minas Gerais}

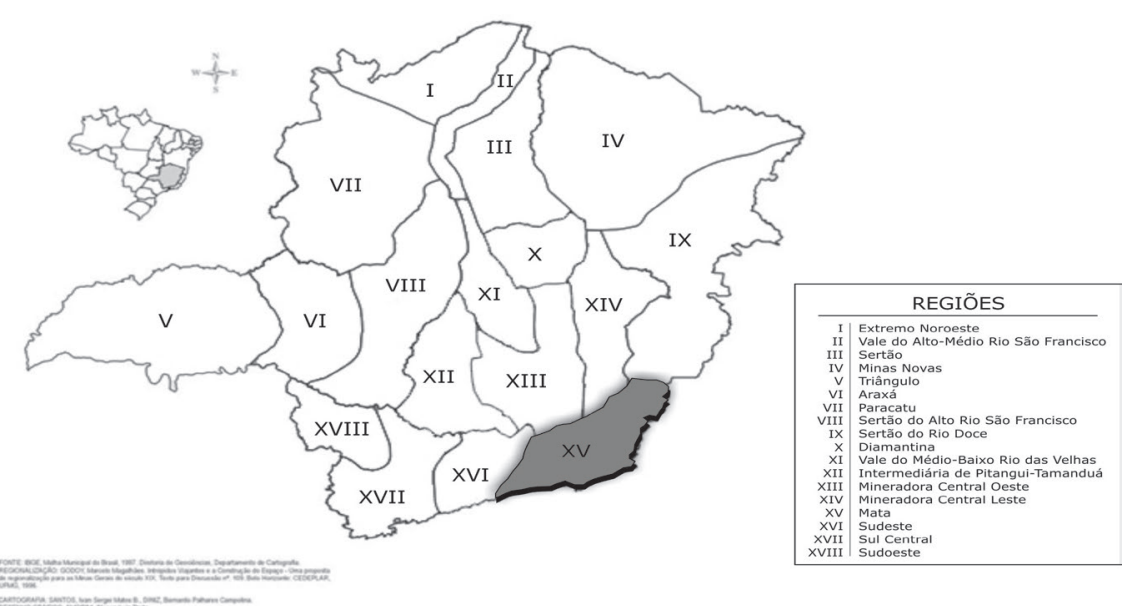

Fonte: Elaboração própria.

A referida região apresentou evolução singular no que tange à infraestrutura viária, tanto pela construção da estrada macadamizada inaugurada no ano de 1861 pela Companhia União e Indústria, como pela inserção ferroviária na década de $1870 .{ }^{3} 0$ desenvolvimento da região da Mata estava atrelado à expansão da cafeicultura e, por conseguinte, era constante a necessidade de escoamento da produção através de vias de comunicação de fácil e seguro acesso. ${ }^{4} 0$ crescimento da produção cafeeira requereu a construção de novas e eficientes vias de comunicação. A melhoria da infraestrutura de comunicações foi condicionada pelos efeitos do crescimento da renda cafeeira na economia regional, assim como pela participação de fazendeiros locais em investimentos na infraestrutura viária. ${ }^{5}$ Apesar dos pronunciados interesses locais, dos benefícios produzidos pelo aperfeiçoamento dos transportes e do significativo crescimento populacional (Tabela 1), a historiografia pouco conhece sobre as estradas e pontes edificadas na região da Mata para além dos domínios geográficos da Estrada da Companhia União e Indústria, que tinha alcance limitado até a cidade de Juiz de Fora.

Tabela 1 - Estimativa populacional - Minas Gerais - 1832 e 1872

\begin{tabular}{|c|c|c|c|c|c|c|c|c|c|c|c|c|}
\hline \multirow{4}{*}{ Região } & \multicolumn{6}{|c|}{ População 1832} & \multicolumn{6}{|c|}{ População 1872} \\
\hline & \multicolumn{4}{|c|}{ Condição } & \multirow{2}{*}{\multicolumn{2}{|c|}{ Total }} & \multicolumn{4}{|c|}{ Condição } & \multirow{2}{*}{\multicolumn{2}{|c|}{ Total }} \\
\hline & \multicolumn{2}{|c|}{ Livre } & \multicolumn{2}{|c|}{ Escravo } & & & \multicolumn{2}{|c|}{ Livre } & \multicolumn{2}{|c|}{ Escravo } & & \\
\hline & N. & $\%$ & N. & $\%$ & $\mathrm{~N}$. & $\%$ & N. & $\%$ & $\mathrm{~N}$. & $\%$ & $\mathrm{~N}$. & $\%$ \\
\hline Mata & 29.882 & 5,2 & 21.237 & 7,7 & 51.119 & 6,0 & 201.145 & 11,8 & 81.307 & 21,5 & 282.452 & 13,6 \\
\hline
\end{tabular}

Província

de Minas 572.099 100,0 276.098 100,0 848.197 100,01.705.419 100,0 378.126 100,0 2.083.545 100,0 Gerais

Fonte: RODARTE, Mario Marcos Sampaio. 0 trabalho do fogo: domicilios ou famílias do passado - Minas Gerais, 1830. Belo Horizonte: Editora UFMG, 2012. p.102-104. 
Revista do Dep. de História da UFF, Niterói, v.15, n.30, p.245-246, jan-jul.2011. Ver, MELO, Hildete Pereira de. Café e ferrovias: Rio de Janeiro e Minas Gerais 1850/1910. Anais do VII Seminário sobre Economia Mineira. Diamantina: Cedeplar/UFMG, 1995.

5

BLASENHEIM, Peter. As ferrovias de Minas Gerais no século dezenove. Locus: Revista de História, Juiz de Fora, v.2, n.2, p.86, jul-dez/1996.

6

Para uma análise da evolução e penetração das ferrovias em Minas Gerais, ver: BATISTA, Felipe Alvarenga; BARBOSA, Lidiany Silva; GODOY, Marcelo Magalhães. Transportes, modernização e formação regional - Subsídios à história da era ferroviária em Minas Gerais, 1870-1940. Revista de História Regional, v.17, n.1, p.162-203, 2012.

7

No âmbito da economia, enfatiza-se a natureza descontínua do progresso técnico: "For economics and economic history, the import of the distinction between invention/innovation, diffusion, and impact is so well-known as to be obvious. Yet in economic history the dominant tradition of thinking about technology has been shumpeterian in inclination, and thus very innovation-centric (...)". EDGERTON, David. Innovation, technology, or history what is the historiography of technology about? Technology and Culture, v.51, n.3, p.689, 2010.

8

PRADO Jr, Caio. História Econômica do Brasil. 12a edição. São Paulo: Brasiliense, 1970. p.196197; MOTOYAMA, Shozo (org). Tecnologia e industrialização no Brasil. São Paulo: Unesp, 1994. p.29-31.

9

Sobre a importância em superar a visão da modernização enquadrada na estreita relação ferrovia e atividade exportadora. Cf. GODOY, Marcelo Magalhães; BARBOSA, Lidiany Silva. Uma outra modernização: transportes em uma província não-exportadora - Minas Gerais, 1850-1870. Economia e Sociedade. v.17, n.2, p.159-186, 2008.

10

A receita com base na circulação interprovincial alcançava, em média, quase $67 \%$ da arrecadação no período de 1835 a 1889: "(...) evidencia que a arrecadação tributária baseava-se prioritariamente nas relações comerciais de Minas com outras provincias e exterior". Cf. BARBOSA, Lidiany; GODOY, Marcelo; MENDES, Philipe. Transporte e finanças públicas: contribuição para o estudo do lugar do dispêndio em infraestrutura viária nos orçamentos provinciais e municipais de Minas Gerais 1835-1889. In: FILHO, Alcides; QUEIROZ, Paulo Roberto Cimó (org). Transportes e Formação regional: contribuições à História dos Transportes no Brasil. Dourados: Ed. UFGD, 2011. p.237-242.

11

RESTITUTTI, Cristiano Corte. Elementos da fiscalidade de Minas Gerais provincial. Almanack Braziliense, São Paulo, n. 10, p.115-129, 2009.
Em assim sendo, teriam as abordagens da História Econômica e Social contribuído para compreender a dinâmica dos transportes na região cafeicultora da Mata mineira? Para responder essa questão pretende-se desenvolver neste trabalho os seguintes aspectos: quais seriam os impulsos gerados pelo comércio interprovincial na modernização de pontes e estradas? Qual a importância da Engenharia e dos engenheiros na construção do modal não-ferroviário? ${ }^{6}$

0 presente estudo está dividido em três partes. Na primeira delas, intitulada "Fiscalidade, Engenharia e trânsito mercantil em uma região agroexportadora", demonstra-se o impacto do arranjo institucional do Império na constituição de um aparato fiscal na província de Minas Gerais, dentro do qual as estradas e pontes exerceram importante função para a geração de divisas para os cofres públicos através da circulação mercantil interprovincial. Argumenta-se que os engenheiros provinciais atuaram como intermediários entre a necessidade de melhorias e aperfeiçoamentos em estradas e pontes e os interesses provinciais no âmbito administrativo. Ou seja, os engenheiros, enquanto funcionários de segundo escalão, nomeados pelo poder político, exerceram sua função em consonância com os interesses do aparato burocrático e fiscal da província. Daí a junção entre a técnica, a ciência e a economia provincial.

Na segunda parte, "Patente, difusão e fracasso: de uma margem a outra em barcas ou a construção de uma ponte pênsil sobre o Rio Paraiba?", visa-se contribuir para a análise do Sistema de Patente do Brasil (1830) e identificar os fatores que conduziram ao fracasso a tentativa de construção de uma ponte pênsil sobre o Rio Paraiba.

Por fim, em "Modernização esquecida: mercado, engenheiros, artífices e um 'velho artefato' de madeira e pedra sobre o Rio Paraíba", analisamos a construção de uma ponte na região da Mata mineira, privilegiando quatro aspectos: I) a construção implicou a formação de uma teia de relações entre engenheiros, empreiteiros, artífices e a administração provincial; II) o aprimoramento de um "velho" artefato tecnológico, isto é, uma ponte de madeira e pedra, através da atuação de engenheiros provinciais e de engenheiros de diferentes companhias ferroviárias, propiciou o aperfeiçoamento da dita ponte ${ }^{7}$; III) edificar a ponte contemplou parte do processo de integração do mercado interno através da ampliação das articulações inter-regionais, visando atender a circulação mercantil e de pessoas entre Minas Gerais e a cidade cafeicultora de Cantagalo; IV) a presença de expressivos fomentos para a modernização técnica na construção viária tradicional contraria a tese propagada pela historiografia da existência de um modelo único de modernização dos transportes, mormente ferroviário $^{8}$, e da pouquissima consideração acerca das particularidades de outra modernização dos transportes em espaços mercantis internos. ${ }^{9}$

Fiscalidade, Engenharia e trânsito mercantil em uma região agroexportadora A partir de 1834, o arranjo institucional do periodo Imperial permitiu a autonomia fiscal para o controle das rendas no âmbito da estrutura organizacional das províncias. As assembleias provinciais adquiriram a competência de decidir acerca dos aspectos relativos à infraestrutura viária.

Na província de Minas Gerais, dentre os mecanismos de geração de receita havia a cobrança de taxas itinerárias. ${ }^{10}$ Os postos fiscais responsáveis pela arrecadação das taxas itinerárias eram denominados de Recebedorias. ${ }^{11}$ Estas, por sua vez, situavam-se às margens de rios, em áreas 
MARTINS, Roberto Borges; MARTINS, Maria do Carmo Salazar. As exportações de Minas Gerais no século XIX. Revista Brasileira de Estudos Políticos, n.58, p.116-120, 1984

13

Livro da Lei Mineira, 1859, Lei 869, art 3. Ver: RESTITUTTI, Cristiano Corte. Op. Cit., p.118.

14

DOLHNIKOFF, Miriam. 0 pacto Imperial: origem do federalismo no Brasil do século XIX. São Paulo: Globo, 2005. p. 112 .

Livro da Lei Mineira 1866, R 55, art. 2, 3 e 4 limítrofes da província e em locais de intensa circulação de bens e pessoas. As Recebedorias ficaram incumbidas de efetuar cobranças sobre o trânsito interprovincial, incidindo taxas pecuniárias sobre muares importados e gêneros de exportação (café, suínos, bovinos, algodão, fumo, tecidos, toucinho, feijão). ${ }^{12}$ Por outro lado, a legislação isentava de tributação outros artigos, tais como: sal, instrumentos aratórios e objetos tendentes a desenvolver a indústria manufatureira. ${ }^{13}$ Em vista disso, defendia-se a necessidade de investimento em transporte como estratégia para o crescimento econômico. ${ }^{14}$

De acordo com o Regulamento de 1866, trinta e uma Recebedorias compunham o aparato fiscal e de geração de divisas para a receita da província. 0 Regulamento dividiu as Recebedorias em quatro classes diretamente proporcionais aos seus respectivos rendimentos. ${ }^{15}$

Nota-se que doze Recebedorias, isto é, $38,7 \%$, se encontravam na região da Mata mineira, como se observa na tabela 2.

Tabela 2 - Recebedorias situadas na região da Mata mineira, segundo a classificação por classe

\begin{tabular}{lll}
\hline Classe & Região & Recebedoria \\
\hline $1^{\circ}$ & Mata & Paraibuna \\
\hline $1^{\circ}$ & Mata & Presidio do Rio Preto \\
\hline $1^{\circ}$ & Mata & Mar de Espanha \\
\hline $1^{\circ}$ & Mata & Sapucaia \\
\hline $2^{\circ}$ & Mata & Porto Novo do Cunha \\
\hline $2^{\circ}$ & Mata & Barra do Pomba \\
\hline $2^{\circ}$ & Mata & Três llhas \\
\hline $2^{\circ}$ & Mata & Flores do Rio Preto \\
\hline $2^{\circ}$ & Mata & Gameleira \\
\hline $3^{\circ}$ & Mata & Patrocinio \\
\hline $3^{\circ}$ & Mata & Porto Velho do Cunha \\
\hline $3^{\circ}$ & Mata & Porto do Avellar \\
\hline & &
\end{tabular}

Fonte: Livro da Lei Mineira, 1866, Regulamento 55, artigos 2, 3 e 4.

Nenhuma das Recebedorias da região da Mata ocupava a categoria denominada $4^{\text {a }}$ classe, composta, exclusivamente, pelas Recebedorias de menor rendimento. As doze Recebedorias se subdividiam da seguinte forma: quatro compunham a $1^{\text {a }}$ classe $(33,3 \%)$; cinco estavam na $2^{\text {a }}$ classe $(41,6 \%)$ e três foram classificadas como pertencentes à $3^{\text {a }}$ classe $(25,1 \%)$. Revela-se, assim, que a divisão tributária estabelecida pelo Ato Adicional (1834) dotava a Assembleia Legislativa da província de Minas Gerais de mecanismos para a elaboração de uma política econômica fiscal. Para a composição desta politica tributária a província se utilizou de um corpo técnico (engenheiros e desenhistas) para mensurar, mapear e identificar a circulação de bens, pessoas e ideias, como se pode vislumbrar na produção cartográfica Mappa das Colletorias, Recebedorias e seos estravios, Linhas de Correios e suas ramificações da Província de Minas Geraes (1865). Através desta representação cartográfica, pode-se observar as cidades interligadas pelas linhas dos correios, a localização das Recebedorias e das Coletorias, os números de extravios e a presença de uma hierarquia urbana (Vilas, Cidades, Arraiais). 
Figura 2 - Mapa das Coletorias, Recebedorias e seus extravios, Linhas de Correios e suas ramificações da Província de Minas Gerais - João R. Duarte, desenhador copista da Diretoria Geral de Obras Públicas sob a inspeção do Eng. Aroeira, em junho de 1865

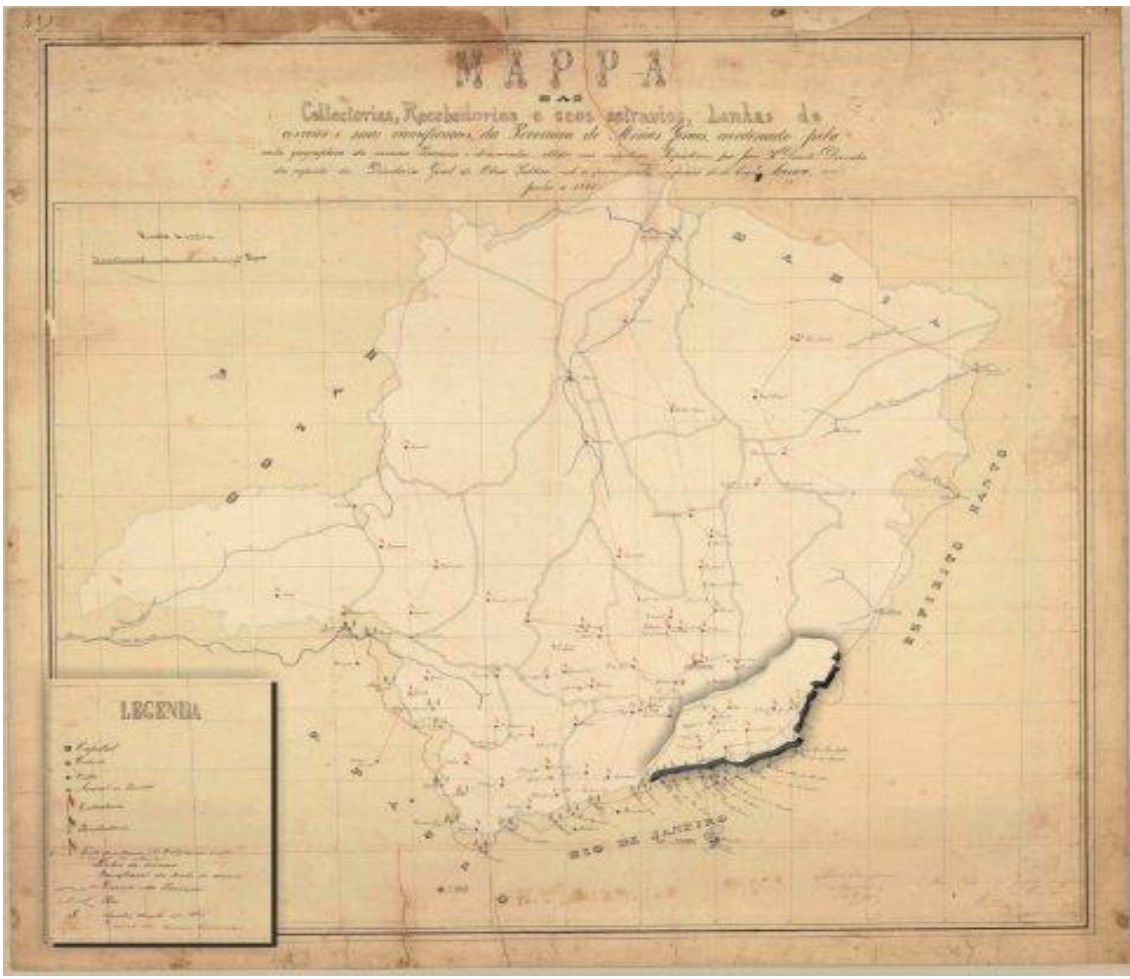

Fonte: Arquivo Público Mineiro, OP-013.

0 registro cartográfico manifesta a representação de uma territorialidade específica. Se de um lado prevalecem informações acerca dos elementos que compõem a circulação mercantil e de ideias (correios, estradas, rios), de outro temos a delimitação do espaço limítrofe da fronteira administrativa e do aparato fiscal (divisa da província, Recebedorias e Coletorias):

0 termo território deve ser compreendido como um artefato cultural, produzido através de complexas interações econômicas e por diversos atores sociais. A cartografia se torna um conjunto documental, no qual se expressam distintos elementos constitutivos da territorialidade, ou seja, ela expressa um artefato social, uma construção histórica, resultante da ação humana.

A produção cartográfica também contém em si as concepções de mundo, as convenções, os códigos de representação de cada período, a utilização de instrumentos científicos. 0 Engenheiro apropria-se do espaço, nomeia, indica a hierarquia de Vilas, Arraiais, Cidades e delimita as divisas e os limites do território. ${ }^{16}$

CRAVO, Télio A. Engenharia, engenheiros e o universo da difusão de tecnologia no Brasil Imperial: patente, projeto e construção de uma ponte lattice em Minas Gerais (1860-1864). Revista Brasileira de História da Ciência, Rio de Janeiro, v.5, n.2, p.359, jul-dez/2012.
Atenta-se que em linhas contínuas de cor vermelha estão representadas as ligações postais, as linhas dos correios, e, em bandeiras de cor verde, a localização das Recebedorias. Tais características podem ser vislumbradas através do excerto abaixo, que privilegia a região da Mata mineira: 
17

Livro da Lei Mineira 1858, Lei 957, art. 1.

18

0 Engenheiro Henrique Gerber realizou os exames técnicos com o auxílio do ajudante Gustavo Dodt. Gustavo Luis Guilherme Dodt foi contratado pelo Barão de Capanema para serviços no Ministério e para a construção de linhas telegráficas. Era natural do Reino de Hannover e formado em engenharia e também doutor em filosofia pela Universidade de lena. Uma das dificuldades apontadas pelos engenheiros eram os acentuados declives dos caminhos que partiam da Vila de Mar de Espanha para os Portos do Chiador ou Mar de Espanha, Porto Novo do Cunha, Sapucaia e Porto Velho do Cunha. Assim, aconselharam 0 abandono das antigas estradas e a abertura de uma nova via de comunicação. Cf. Relatório que ao Illmo Exm. Sr. Dr. Joaquim Delfino Ribeiro da Luz entregou ao IIIm. e Exm. Sr. Conselheiro Carlos Carneiro de Campos de seguir para a Vila de Lavras a fim de assistir as arrematações da estrada do Passa Vinte. Ouro Preto, Typographia Provincial, 1859. p.27-28.

19

Henrique Gerber desempenhou as atividades de engenheiro da província de Minas Gerais entre fins da década de 1850 até 0 ano de 1867: "Nascido na Allemanha e brazileiro por naturalisação, sendo engenheiro, serviu na província, hoje estado de Minas Gerais, é cavaleiro da ordem da Rosa, e escreveu: Noções geographicas e administrativas da provincia de Minas Geraes, publicada em virtude do art. 21 da lei n.1.164 de outubro de 1861, com uma planta de Ouro Preto. Rio de Janeiro, 1863". Cf. BLAKE, Augusto Vitorino A. Sacramento. Diccionário Bibliographico Brasileiro. Rio de Janeiro: 1895, vol.03, p.220.

20

Arquivo Público Mineiro, SPOP 3-1, caixa 1, doc.05.

21

Ibidem.

22

Para as transformações do sistema de pesos e medidas do século XIX (braça, palmo, légua etc) utilizamos a obra do engenheiro provincial Modesto de Faria Bello. Cf. BELLO, Modesto de Faria. Tabellas do novo systema de pesos e medidas e principalmente da reducção das antigas medidas agrárias às do systema métrico e viceversa. Rio de Janeiro: Typ. de Adolpho de Castro \& Cia, 1882.
Figura 3 - Excerto do Mapa das Coletorias, Recebedorias e seus extravios, Linhas de Correios e suas ramificações da Província de Minas Gerais.

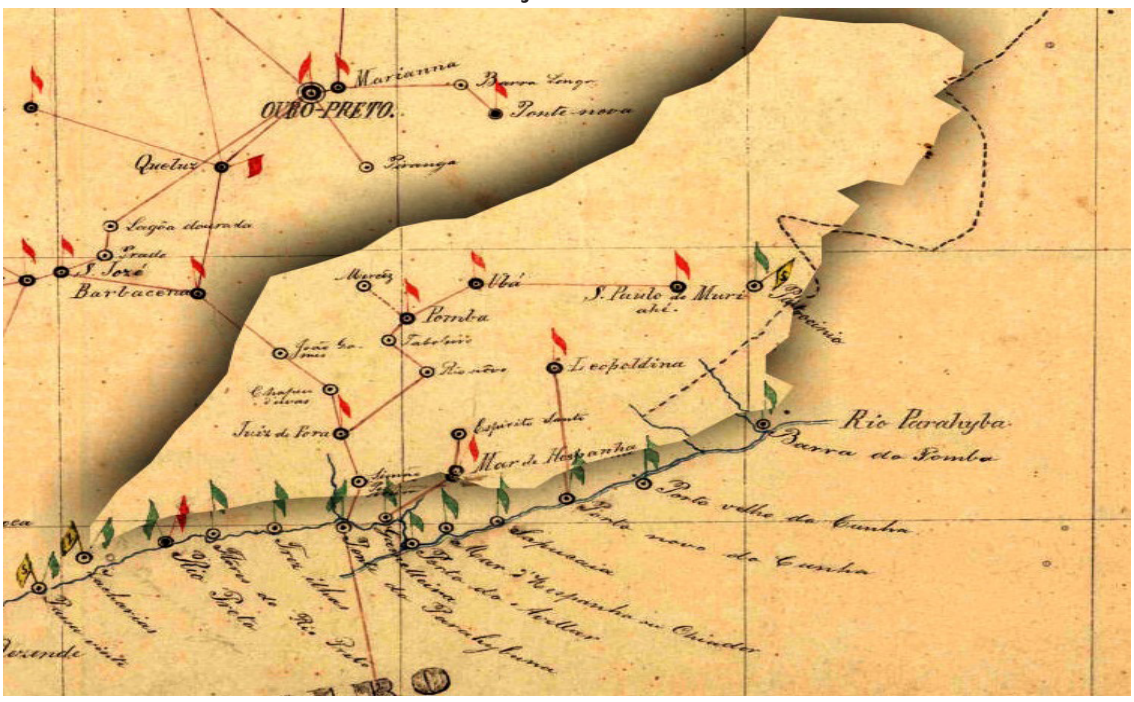

Fonte: Arquivo Público Mineiro, OP-013.

Através da lei n.957 de junho de 1858, a província de Minas autorizou a construção de um ramal de estrada ligando a Vila do Mar de Espanha à estrada da Companhia União e Indústria no ponto denominado Três Barras. ${ }^{17}$ No ano seguinte, em 1859, o Engenheiro Henrique Gerber ${ }^{18}$ apresentou um extenso relatório com detalhes técnicos e econômicos sobre a edificação da estrada entre Mar de Espanha e o ponto de Três Barras na estrada da Companhia União e Indústria. ${ }^{19}$

Henrique Gerber atentou para os fluxos comerciais de exportação de café e outros gêneros, assim como as taxas itinerárias incididas sobre muares, porcos, ovelhas e cabras. ${ }^{20} 0$ Engenheiro efetuou uma extensa compilação estatística do volume de circulação em quatro Recebedorias: Ericeira, Mar de Espanha, Sapucaia e Porto Novo do Cunha. Para isso, utilizou os dados dos anos financeiros de 1854-55, 1855-56, 1856-57, bem como realizou estudos sobre a topografia e a hidrografia, visando atender aos preceitos técnicos de modo que a estrada nunca excedesse a declividade de $3 \%$ ao longo do percurso. ${ }^{21}$ Por fim, apresentou a seguinte proposta de construção: ${ }^{22}$

Tabela 3 - Estrada entre uma ponte sobre o Rio Paraíba até a Vila de Mar de Espanha (1859)*

\begin{tabular}{cccc}
\hline Trajeto & Distância $(\mathrm{Km})^{* *}$ & Prazo de conclusão & Preço total \\
\hline $\begin{array}{l}\text { Início: ponte sobre o Rio } \\
\text { Paraiba na estrada União } \\
\text { e Indústria }\end{array}$ & & & \\
Término: Vila de Mar & 54,450 quilômetros & 14 a 18 meses & $1: 188: 000 \$ 000$ \\
de Espanha & & & \\
\hline
\end{tabular}

Fonte: Arquivo Público Mineiro, SPOP 3-1, caixa 1, doc.05.

*A estrada seria construída em parceira com a província do Rio de Janeiro, posto que 4.950 quilômetros de seu comprimento estavam na referida província e, o restante, 54.450 quilômetros, se encontravam em Minas Gerais, atingindo, com isso, o comprimento total de 59.400 quilômetros. Apenas consideramos nesse cálculo o trecho de Minas Gerais.

**Para a transformação de cada légua em quilômetro se utilizou a seguinte razão: 1 légua = 6.600 quilômetros. 
0 diagnóstico do fluxo de circulação elaborado pelo engenheiro Henrique Gerber contribuiu para a seleção do traçado (ver tabela 4). Somando o volume de exportação de café nas quatro Recebedorias levadas em conta (Ericeira, Sapucaia, Mar de Espanha e Porto Novo do Cunha), alcança-se a totalidade de 23,7 toneladas exportadas entre os anos financeiros de 1854 a 1857. Se considerarmos que toda a exportação de café se realizou por meio de mulas, temos a estimativa de uma circulação de 202.460 muares em um intenso fluxo interprovincial para os três anos financeiros.

Tabela 4 - Exportação de café, Recebedorias e estimativa de muares (1854-1857)

\begin{tabular}{|c|c|c|c|c|}
\hline \multirow{2}{*}{$\begin{array}{c}\text { Ano } \\
\text { Financeiro* }\end{array}$} & \multirow{2}{*}{ Recebedoria } & \multicolumn{2}{|c|}{ Exportações de café } & \multirow{2}{*}{$\begin{array}{c}\text { Estimativa de muares } \\
\mathrm{N}^{\circ}\end{array}$} \\
\hline & & Toneladas & $\%$ & \\
\hline \multirow{5}{*}{$1854-1855$} & Ericeira & 1.8 & 2,7 & 1.606 \\
\hline & Mar de Espanha & 2.5 & 36,8 & 21.891 \\
\hline & Sapucaia & 2.0 & 30,0 & 17.860 \\
\hline & Porto Novo do Cunha & 2.1 & 30,4 & 18.100 \\
\hline & Total & 6.9 & 100,0 & 59.457 \\
\hline \multirow{5}{*}{$1855-1856$} & Ericeira & 0.4 & 7,0 & 4.154 \\
\hline & Mar de Espanha & 2.5 & 36,7 & 21.561 \\
\hline & Sapucaia & 2.0 & 30,3 & 17.826 \\
\hline & Porto Novo do Cunha & 1.7 & 25,8 & 15.172 \\
\hline & Total & 6.8 & 100,0 & 58.713 \\
\hline \multirow{5}{*}{$1856-1857$} & Ericeira & 0.6 & 6,8 & 5.735 \\
\hline & Mar de Espanha & 3.2 & 32,3 & 27.313 \\
\hline & Sapucaia & 3.3 & 33,8 & 28.573 \\
\hline & Porto Novo do Cunha & 2.6 & 26,8 & 22.669 \\
\hline & Total & 9.9 & 100,0 & 84.290 \\
\hline \multicolumn{2}{|c|}{ Total 1854-1857 } & 23.7 & 100,0 & 202.460 \\
\hline
\end{tabular}

Fonte: Arquivo Público Mineiro, SPOP 3-1, caixa 1, doc.05. As arrobas foram convertidas para quilogramas, tendo como base a razão de 1 arroba $=14,689$ quilos.

${ }^{*} 0$ ano financeiro iniciava-se no dia $1^{\circ}$ de julho e findava em 30 de junho.

* Para o cálculo do número dos muares em circulação se utilizou como base de cálculo a capacidade média de transporte de 8 arrobas por animal (Cf. CRAV0, Télio Anísio; GODOY, Marcelo M. Por estradas e caminhos do interior do Brasil oitocentista. Anais do XIV Seminário Sobre Economia Mineira. Diamantina: Cedeplar/UFMG, 2010. p.14).

Temos, portanto, para o triênio 1854-1857, uma média de 7.9 toneladas de exportação de café e de 67.400 mulas utilizadas nesse transporte, circulando nos caminhos que seguiam em direção ao Rio de Janeiro. A Recebedoria de Mar de Espanha apresentava a maior quantidade exportada de café para o triênio: 8.3 toneladas e uma média anual de 2.7 toneladas. Em seguida, a Recebedoria de Sapucaia indicava uma totalidade de 7.5 toneladas exportadas, sendo a média anual de 2.5 toneladas de café. Em termos comparativos, a média de exportação de café em circulação na região da Mata compreendia 6.1\% da produção total exportada pelo país entre os anos de 1854 e 1857. 
Tabela 5 - Média de exportação de café, 1854-1857

Arquivo Público Mineiro, SPOP 3-1, caixa 1 doc.05.

24

KRANAKIS, Eda. Constructing a bridge:an exploration of engineering culture, design, and research in nineteenth-century France and America. Cambridge: MIT Press, 1997.

25

KRANAKIS, Eda. Op. Cit., p.40-61.

26

MATOS, Artur Teodoro de. Transportes e comunicações em Portugal, Açores e Madeira (1750-1850). Ponta Delgada [Portugal]: Universidade dos Açores, 1980. p.217.

\begin{tabular}{ccccc}
\hline & \multicolumn{2}{c}{ Brasil } & \multicolumn{2}{c}{ Minas Gerais* $^{*}$ Período } \\
\cline { 2 - 4 } & Toneladas & $\%$ & Toneladas & $\%$ \\
\hline $1854 / 57$ & 128.1 & 100.0 & 7.9 & 6.1 \\
\hline
\end{tabular}

Fonte: Arquivo Público Mineiro, SPOP 3-1, caixa 1, doc.05 (Cf. SOARES, Sebastião Ferreira. Notas estatísticas sobre a produção agrícola e carestia dos gêneros alimentícios no Império do Brasil. Rio de Janeiro: IPEA/INPES, 1977. p.17-31).

*Dados de exportação de café das seguintes Recebedorias: Ericeira, Mar de Espanha, Sapucaia e Porto Novo do Cunha.

A compilação estatística fornecida para as referidas Recebedorias não se restringia aos dados de exportação de café. Com ela tem-se acesso à dados sobre o trânsito de porcos, ovelhas e cabras na esfera interprovincial. Embora estejam em proporção reduzida em relação ao montante exportado de café, não se deve diminuir a importância deste fluxo interprovincial, que alcançou para o triênio financeiro um fluxo médio de 5.394 animais (porcos, ovelhas e cabras). ${ }^{23}$

Em seguida, privilegiaremos a análise do registro de patente de uma ponte pênsil, obtida no ano de 1858 , e a proposta de construção da dita ponte em Porto Novo do Cunha, que registrava, em termos médios para os anos fiscais de 1854/57, a passagem de 2,2 toneladas de café e 18.647 de muares em trânsito interprovincial. Esse fluxo mercantil interprovincial se utilizava de embarcações fluviais em Porto Novo do Cunha para a travessia de uma margem a outra do Rio Paraíba, como se observará a seguir.

Patente, difusão e fracasso: de uma margem a outra em barcas ou a construção de uma ponte pênsil sobre o Rio Paraíba?

Em 1808, James Finley patenteou nos Estados Unidos a moderna ponte pênsil. A inovação se difundiu rapidamente pela Grã-Bretanha e França. 0 francês Claude Navier publicou, em 1823, um tratado sobre as pontes suspensas. ${ }^{24}$ Navier, engenheiro do Corps des Ponts et Chaussées, procurou adaptar a ponte suspensa às tradições e objetivos da arquitetura francesa. Assim, o design desenvolvido para a construção de ponte suspensa era elegante, monumental, requeria considerável quantia pecuniária e alto nivel de conhecimento técnico. Por outro lado, o design proposto por Finley era dimensionado por três objetivos, que revelavam a interação entre inovação, tecnologia e a sociedade dos Estados Unidos no século XIX: I) design econômico para construir e conservar; II) possibilidade de ser construída e reparada por ferreiros e carpinteiros dada a facilidade de compreensão; III) reconhecia que o design da ponte deveria ser adaptado às condições locais existentes.

A ponte pênsil difundiu-se inserida em um contexto do sistema de patente americano, que concedeu ao inventor James Finley o direito de monopólio de dezessete anos para a exploração da inovação. Observa-se que, no início do século XIX, havia poucos engenheiros civis formados nos Estados Unidos e, portanto, a difusão da ponte suspensa dependia da habilidade de artesãos locais. ${ }^{25}$

Em Portugal, a construção da primeira ponte pênsil se realizou com o auxílio de engenheiros franceses. Em 1841 teve iníciou sua construção e, após dois anos, ela foi inaugurada na cidade do Porto. ${ }^{26}$ 
27

Decreto n.2136 de 27 de março de 1858: "(...) hei por bem conceder-Ihe por vinte anos para a sua invenção de construcção de pontes e aqueductos pensis constante das descrições e desenhos que apresentou, e que ficão competentemente archivado" (Colleção das Leis do Império do Brasil), 1858, tomo XIX, 2a parte, decreto n. 2.136).

28

A Lei de Patentes de 1830 era composta por dez artigos. Dentre esses destacam-se os seguintes:

"Concede privilégio ao que descobriu, inventar ou melhorar uma industria util e um premio ao que introduziu uma industria estrangeira, e regula sua concessão. (...) Art $1^{\circ}$ - A lei assegura ao descobridor, ou inventor de uma industria util a propriedade e o uso exclusivo de sua descoberta ou invenção. Art $2^{\circ}-0$ que melhorar uma descoberta, ou invenção, tem no melhoramento o direito de descobridor, ou inventor. Art $3^{\circ}-\mathrm{Ao}$ introductor de uma industria estrangeira se dará um prêmio proporcionado a utilidade, e dificuldade da introdução. (...) Art $5^{\circ}$ - As patentes se concederão segundo a qualidade da descoberta, ou invenção, por espaço de cinco até vinte annos (...). Art $6^{\circ}$ - Se o Governo comprar o segredo da invenção, ou descoberta, fal-o-ha publicar; no caso, porém, de ter unicamente concedido patente, o segredo se conservará occulto até que expire o prazo da patente. Findo este, é obrigado o inventor ou descobridor a patentear o segredo". Coleção das Leis do Império do Brasil, 1876, Lei de 1830, art $1^{\circ}, 2^{\circ}, 3^{\circ}, 5^{\circ}$ e $6^{\circ}$.

29

MALAVOTA, Leandro Miranda. Inovar, modernizar, civilizar: considerações sobre o sistema de patentes no Brasil (1809-1882). Tese (Doutorado em História Social). Programa de Pós-Graduação em História Social, Universidade Federal Fluminense, Niterói, 2011. p.160-164.

30

CERQUEIRA, João da Gama. Evolução Histórica da Propriedade Intelectual no Brasil. In: Idem. Tratado de Propriedade Industrial. Rio de Janeiro: Edição Revista Forense, 1946, tomo I, vol. 01 p.32. Deve se destacar que a ponte pênsil já havia sido construida no Brasil. 0 engenheiro francês Louis Léger Vauthier, que exerceu a função de chefe da Repartição de Obras Públicas na província de Pernambuco entre 1840 e 1846, ergueu, em 1842, a ponte pênsil de Caxangá sobre o Rio Capibaripe. Cf. FREYRE, Gilberto. Um engenheiro francês no Brasil. Rio de Janeiro: José Olympio, 1960, tomo. I, p.348-363.

31

Coleção das Leis do Império do Brasil, 1876, Lei de 1830 , art.10.
Figura 4 - Ao fundo, a primeira ponte pênsil construída em Portugal, na cidade do Porto - 1843.

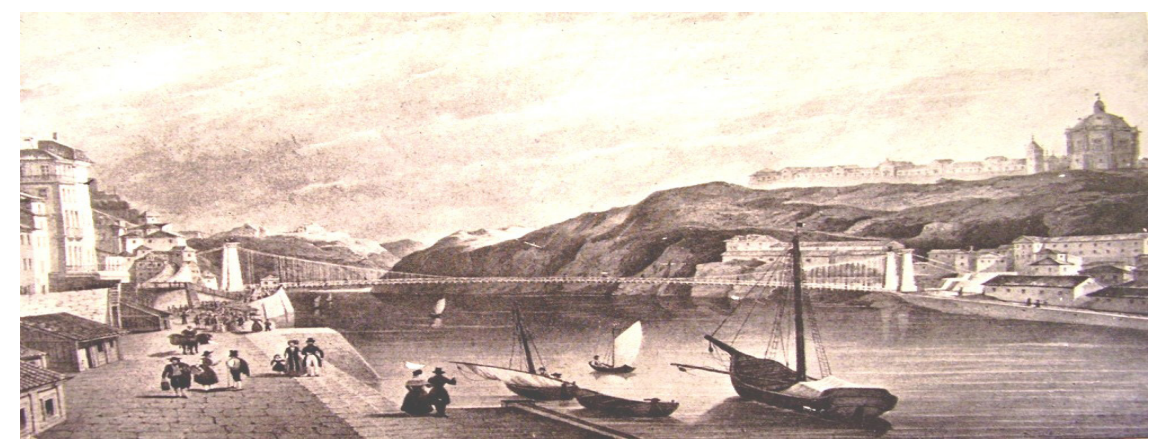

Fonte: Câmara Municipal do Porto. Centenário da Ponte Pênsil: exposição comemorativa inaugurada no dia 17 de fevereiro de 1943. Porto: Câmara Municipal do Porto/Gabinete de História da Cidade, 1943.

Já no Brasil, em 1858, o português Antonio Joaquim Pereira de Carvalho adquiriu o privilégio para a exploração de construção de pontes e aquedutos pensis para o periodo de vinte anos. ${ }^{27} \mathrm{~A}$ concessão da patente da ponte e aqueduto pênsil baseou-se nas normas jurídicas instituídas pela Lei de Patentes de $1830 .{ }^{28}$ Esta concedia iguais condições de privilégio tanto aos inventores quanto aos introdutores de indústrias estrangeiras desconhecidas no Brasil, ou seja, na lei e no uso da norma prevalecia a indistinção entre inovador e introdutor, posto que, no caso deste último, o prêmio se tornava o privilégio de anos. Esse era o caso da patente concedida ao português Antonio Joaquim Pereira de Carvalho. Não havia nenhum dispositivo que impedia aos introdutores obterem o direito de exclusividade de anos. ${ }^{29}$ Havia duas possibilidades para recompensar o introdutor de um artefato estrangeiro desconhecido no país: I) concessão de prêmio pela introdução como, por exemplo, condecoração ou o pagamento pecuniário; II) o privilégio de exclusividade de duração variável (de cinco a vinte anos) de exploração sobre o objeto introduzido no Brasil. Geralmente, optava-se pela concessão do privilégio de anos: "Tal prática parece ter sido adotada por falta de verba orçamentária aos prêmios instituídos pela lei" ${ }^{30}$.

$0 \S 5^{\circ}$ do art. 10 da Lei de patente de 1830 previa que o privilégio de patente poderia cessar caso o beneficiário não colocasse em prática a invenção ou descoberta dentro do prazo de dois anos depois de concedido o direito de patente. ${ }^{31}$ Em vista disso, Antonio Joaquim apresentou uma proposta de edificação de uma ponte pênsil na província de Minas Gerais sobre o Rio Paraiba, nas proximidades do Porto Novo do Cunha. 0 referido Rio constituia-se em uma fronteira natural da divisa entre o Rio de Janeiro e Minas Gerais e um importante obstáculo natural a ser constantemente atravessado pelos animais, cargas e pessoas que realizavam o trânsito mercantil interprovincial em direção à província do Rio de Janeiro.

A proposta foi submetida para avaliação e após a análise da mesma optou-se por empreender a construção da ponte pênsil. A província, em outubro de 1858, firmou contrato com Antonio Joaquim, após os pareceres de duas instâncias burocráticas: 1) a Repartição de Obras Públicas; 2) e a Contadoria da Mesa das Rendas. Ambas foram favoráveis à edificação da dita ponte. A Contadoria da Mesa das Rendas examinou o projeto e declarou o caráter de utilidade pública da ponte já que incrementaria, através do crescimento do trânsito interprovincial, a arrecadação pública e, ao mesmo tempo, desoneraria os cofres da despesa média anual de 2:832\$940 réis com barcas e barqueiros do Porto Novo do Cunha: 
Tabela 6 - Despesa da província com a barca e barqueiros do Porto Novo do Cunha (1854-1857)

\begin{tabular}{cc}
\hline Ano Financeiro $\left(^{*}\right)$ & Despesa (Réis) \\
\hline $1854-1855$ & $2: 210 \$ 000$ \\
\hline $1855-1856$ & $3: 900 \$ 695$ \\
\hline $1856-1857$ & $2: 380 \$ 170$ \\
\hline Total & $9: 490 \$ 865$ \\
\hline \hline Despesa média anual & $2: 832 \$ 940$ \\
\hline \hline
\end{tabular}

Fonte: Arquivo Público Mineiro, SPOP 3-6, caixa 41, doc.17-06.

${ }^{*} 0$ ano financeiro iniciava-se no dia $1^{\circ}$ de julho e findava em 30 de junho.

0 Inspetor Geral das Obras Públicas, José Rodrigues Duarte, dissertou sobre diversos aspectos: I) o local onde se edificaria a ponte; II) a dimensão e os materiais que se utilizariam na obra; III) o modelo de cálculo para alcançar o custo total da obra; IV) a hipoteca geral dos bens ofertada por Antonio Joaquim como garantia para a realização da obra; V) a tendência de crescimento de arrecadação da Recebedoria de Porto Novo do Cunha: 1853-1854 (renda de 9:115\$000 réis), 1854-1855 (acúmulo de 16:158\$098 réis) e 1855-1856 (receita de 12:748\$924 réis). Por fim, ressaltou a utilidade da obra, assim como a viabilidade de execução da ponte pênsil..$^{32}$ Contudo, ainda havia o desconhecimento parcial sobre a largura Arquivo Público Mineiro, SPOP 3-6, caixa 41, doc. 17-02.

33

Segundo Alcir Lenharo, a família Teixeira Leite, da qual fazia parte o Barão de Aiuruoca, havia se enriquecido na região de São João del Rey através do comércio, mineração e pela concessão de empréstimos para a compra de escravos. LENHARO, Alcir. Rota menor: o movimento mercantil da economia de subsistência centrosul do Brasil (1808-1831). Anais do Museu Paulista, São Paulo, vol.XXVIII, p.37, 1977-78: "(...) Custódio Ferreira Leite (futuro Barão de Aiuruoca) (...). De família mineira de São João Del Rey, aventurou-se na região de Vassouras, para onde fez convergir grande número de parentes seus. Antes que se convertesse num dos primeiros cafeicultores de Mar de Espanha, na Zona da Mata mineira, passou longo tempo dedicandose ao serviço de obras públicas, rasgando estradas, construindo pontes, etc. Trouxe dessa etapa os cabedais que lhe permitiriam ligar-se à construção dos trechos finais da estrada da Polícia, já em solo mineiro; disso traria partido, empregando lucrativamente seus escravos nos trabalhos da estrada". LENHARO, Alcir. As tropas da moderação: o abastecimento da Corte na formação política do Brasil, 1808-1842. São Paulo: Símbolo, 1979. p.68.

34

Arquivo Público Mineiro, SPOP 3-6, caixa 41, doc.17-18. do rio, componente essencial do cálculo de custo da obra.

Tabela 7 - Ponte pênsil sobre o Rio Paraíba

\begin{tabular}{|c|c|c|c|c|}
\hline Ano & Localização & Dimensão $\left({ }^{*}\right)$ & Material & Orçamento \\
\hline 1858 & $\begin{array}{c}\text { Próximo ao } \\
\text { Cais do Porto } \\
\text { Novo do Cunha }\end{array}$ & $\begin{array}{c}26,4 \text { metros de } \\
\text { comprimento e } 4,4 \text { metros } \\
\text { de largura }=116,16 \text { metros } \\
\text { quadrados }\end{array}$ & $\begin{array}{c}\text { pedra, cal, } \\
\text { madeira e } \\
\text { ferro }\end{array}$ & $\begin{array}{l}\text { Cada metro quadrado } \\
\text { multiplicado por } 454 \$ 000 \\
\text { réis, sendo o custo total de } \\
52: 800 \$ 000 \text { réis }\end{array}$ \\
\hline
\end{tabular}

Fonte: Arquivo Público Mineiro, SPOP 3-6, caixa 41, doc.17-02.

*Utiliza-se a seguinte razão: 10 palmos = 2,2 metros; cada braça quadrada = 100 palmos quadrados.

Além do desconhecimento exato sobre a largura do Rio Paraiba, a construção da ponte estava condicionada pela seleção do lugar onde seria edificada. 0 início da dita obra somente se realizaria após designação do local exato para construí-la.

A responsabilidade de tal escolha ficou sob a tutela de uma Comissão local nomeada pelo presidente da província. Foram nomeados para compô-la três moradores daquela região: o Comendador Manoel José Monteiro de Castro; Miguel Eugênio Monteiro de Barros (proprietário de fazenda na região de São Paulo do Muriaé e encarregado da construção do Cais do Porto Novo do Cunha); e o Barão de Aiuruoca, proprietário de fazendas em Mar de Espanha. ${ }^{33}$

Em carta enviada ao presidente da província, o Comendador Manoel José Monteiro de Castro agradecia a escolha presidencial para ocupar a Comissão, mas argumentava em prol da construção da ponte pênsil na localidade denominada Ilha dos Pombos, situada entre o Porto Novo do Cunha e Porto Velho do Cunha. Ressaltava duas motivações para a edificação da dita ponte naquela localidade: I) o Rio era mais estreito, sendo apenas de 15,4 metros; II) a Ilha dos Pombos se situava na mesma direção da estrada do Sumidouro que seguia para a província do Rio de Janeiro. ${ }^{34}$ 
Arquivo Público Mineiro, SPOP 3-6, caixa 41, doc.17-24.

37 FREYRE, Gilberto. Op. Cit., p.229.

38

A tentativa de edificar a ponte pênsil, mediada pela impessoalidade do Sistema de Patente de 1830, sucumbiu à presença de privilégios oligárquicos. A manutenção de privilégios é componente, segundo Paula, de uma modernização atrofiada, que reiterou as desigualdades econômicas e sociais, criando um mercado interno incompleto e excludente. $\mathrm{Cf}$. PAULA, João Antonio de. 0 mercado e o mercado interno no Brasil: conceito e história. Revista História Econômica e História de Empresas, São Paulo, v.5, n.1, p. 32-38, 2002.

39

BASSALLA, George. A evolução da tecnologia. Porto: Porto Editora, 2001. p.61-82; ROSENBERG, Nathan. Por dentro da caixa-preta: tecnologia e economia. Campinas: Editora Unicamp, 2006. p.25.

40

Livro da Lei Mineira, 1871, Lei n.1765.
Os trabalhos realizados em conjunto entre a Comissão e o Inspetor Geral de Obras Públicas concluiram que a dita ponte iria alcançar um valor exorbitante, visto que os estudos demonstraram que a largura do rio era extremamente superior à largura que servira de base para a elaboração do contrato, como se vislumbra em correspondência enviada, em 1859, ao presidente da província pelo Inspetor Geral:

[...] reconheceu se que nem no Porto Novo do Cunha em que se projetava colocar a ponte, nem em qualquer outro lugar do dito Rio tem ele uma largura menor de oitenta a cem braças, não se verificando por tanto a hypothese que sérvio de base do dito contrato, pelo qual se contava, ter de construir uma ponte sobre uma largura de doze braças, ou cento e vinte palmos, importando neste caso o seu custo na quantia de cincoenta e dous contos, e oitocentos mil reis $\mathrm{R}^{\mathrm{s}} 52: 800 \$$ indicada na base $5^{\circ}$ do dito contracto. ${ }^{35}$

A partir de então, as cartas enviadas pelo português Antonio Joaquim ao presidente da província passaram a questionar a honestidade do Inspetor Geral e da Comissão em relação à medição da largura do rio:

\footnotetext{
Ninguem acreditará que aqueles ilustres Membros da Comissão, revestidos do seu caráter oficial, desempenhassem um perfeito papel de medo ou comparças por esse silencio completo que [V.Sa] Ihe quer atribuir. [...] eu convidando aqueles ilustres membros para a confecção da acta, um d'elles o Ilmo Comendador Manoel Jose Monteiro de Castro pretendia começar a discutir o meu Contrato, e eu, com os termos mais convenientes e atenciosos Ihe observei que as atribuições da Comissao se limitavam á simples designação do lugar, mas nunca nunca exercer faculdade, que o Governo Provincial, na sua especial nomeação, Ihe não havia dado. ${ }^{36}$
}

Sob a alegação de que o contrato vigorava em base falsa em virtude do desconhecimento da largura real do Rio Paraíba e, portanto, orçado em um valor inverídico, o contrato foi cancelado. Em Minas Gerais, a tentativa de introdução da técnica pênsil não se fez sem querelas: "[...] a influência da técnica estrangeira não se faz sentir [...] sem atritos, ressentimentos, em consequência da competição com agentes de outras culturas e principalmente com os técnicos nacionais e com burocratas e políticos oposicionistas da terra". ${ }^{37}$ Não há, ao longo do processo, nenhum parecer assinado por um engenheiro relativo à medição da largura do Rio Paraíba. A tentativa de introduzir a técnica pênsil, mediada e protegida pelo Sistema de Patente de 1830, se deparou com interesses escusos, privatistas e regionais que estavam inseridos no âmbito da infraestrutura viária da província. ${ }^{38}$

Não se trata de abordar o inventor como um herói, impossibilitado de realizar uma grande benfeitoria e, muito menos, em confundir mudança tecnológica e transformação socioeconômica. Trata-se de revelar a diversidade de elementos que compõem o espectro cultural, político e econômico fundamentais para o ritmo de difusão de uma tecnologia, assim como reconhecer que, para patentear a ponte pênsil, o empreiteiro português Antonio Joaquim Pereira de Carvalho estava em consonância e atento à tecnologia viária produzida externamente seja em Portugal, em França ou nos Estados Unidos. ${ }^{39}$

Modernização esquecida: mercado, engenheiros, artífices e um "velho artefato" de madeira e pedra sobre o Rio Paraíba

Havia já diversas solicitações para a construção de uma ponte sobre o Rio Paraíba na llha dos Pombos. As reivindicações remetiam à década de 1850, mas somente em 1871 a presidência da província autorizou a construção da ponte sobre o Rio Paraiba, no lugar denominado Ilha dos Pombos. ${ }^{40}$ Esta, por sua vez, 
A Câmara Municipal de Leopoldina representou em correspondências dos meses de julho e outubro de 1857 endereçadas ao presidente da província de Minas a importância de uma ponte na Ilha dos Pombos. Ressaltava a conveniência da obra em vista do trânsito interprovincial e afirmava que as tropas com grande demora e prejuizo procuravam a Barra do Porto Novo do Cunha. Cf. Arquivo Público Mineiro, SPOP 3-6, caixa 41 , docs.18-05, 18-07, 18-10, 18-11.

Ibidem, doc.18-44. A construção desta ponte apresenta vínculo direto no uso e posse da terra, assim como impacto no mercado de trabalho. Além disso, essa edificação viária é uma efetiva articulação regional. A combinação desses três elementos (terra, trabalho e transporte) são faces inequivocas da constituição de um mercado interno. Cf. PAULA, João Antonio de. 0 mercado e o mercado interno no Brasil... 0p. Cit., p.17-32. localizava-se aproximadamente a uma distância de doze quilômetros de Porto Novo do Cunha (Figuras 4 e 5). ${ }^{41} 0$ contratante da referida obra, o cidadão José Maria de Souza Passos, segundo o Engenheiro Bruno Von Sperling, apresentava o seguinte interesse econômico para que a ponte fosse edificada: "ele por meio d'esta ponte realisara grande interesse de sua propriedade da ilha que tem área de 80 alqueires, e da qual ele pretende transformar grande parte em pasto".42

Figura 5 - Mapa comparativo da viação férrea ao norte da província do Rio de Janeiro e a leste da de Minas Gerais. Organizada por Edmundo C. Meinicke, 1878.

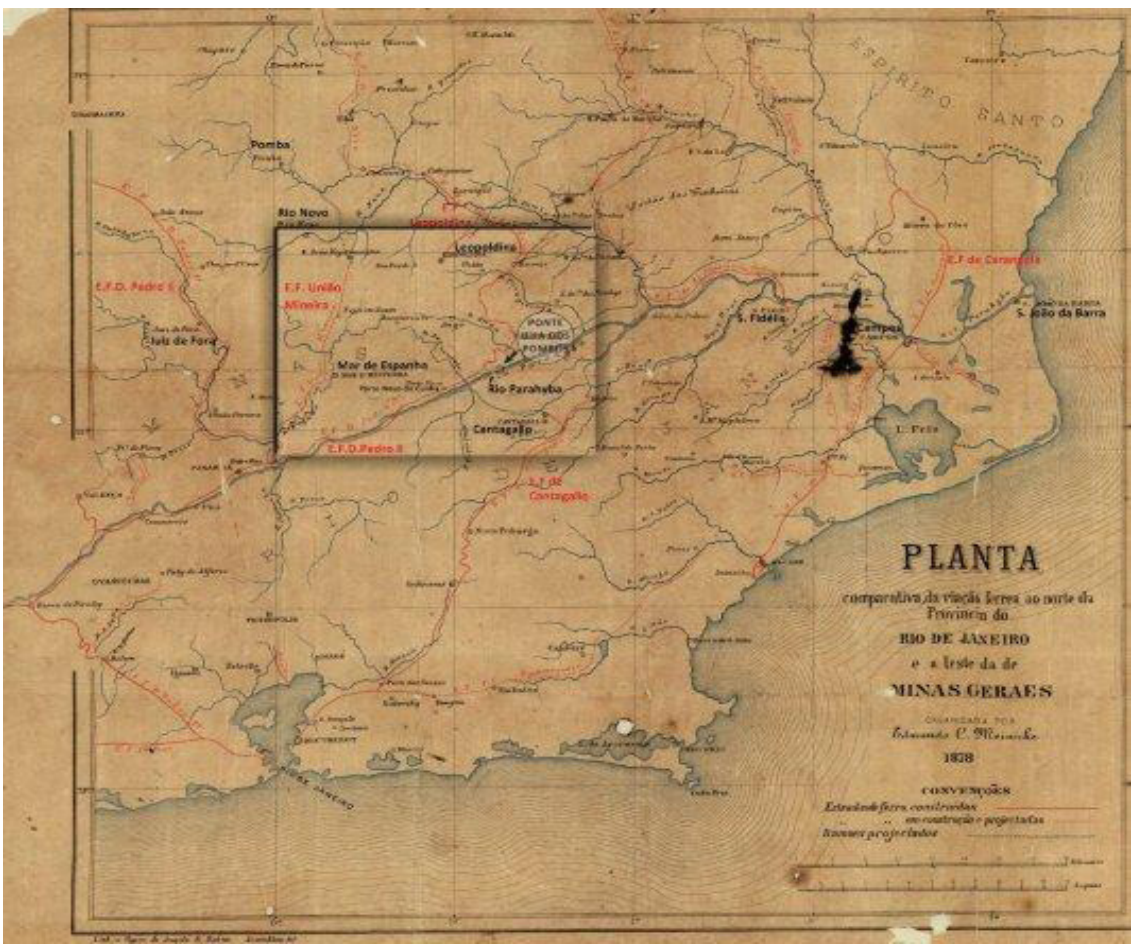

Fonte: Arquivo Público Mineiro, PP-014.

Figura 6 - Excerto do mapa comparativo da viação férrea ao norte da província do Rio de Janeiro e a leste da de Minas Gerais. Organizada por Edmundo C. Meinicke, 1878.

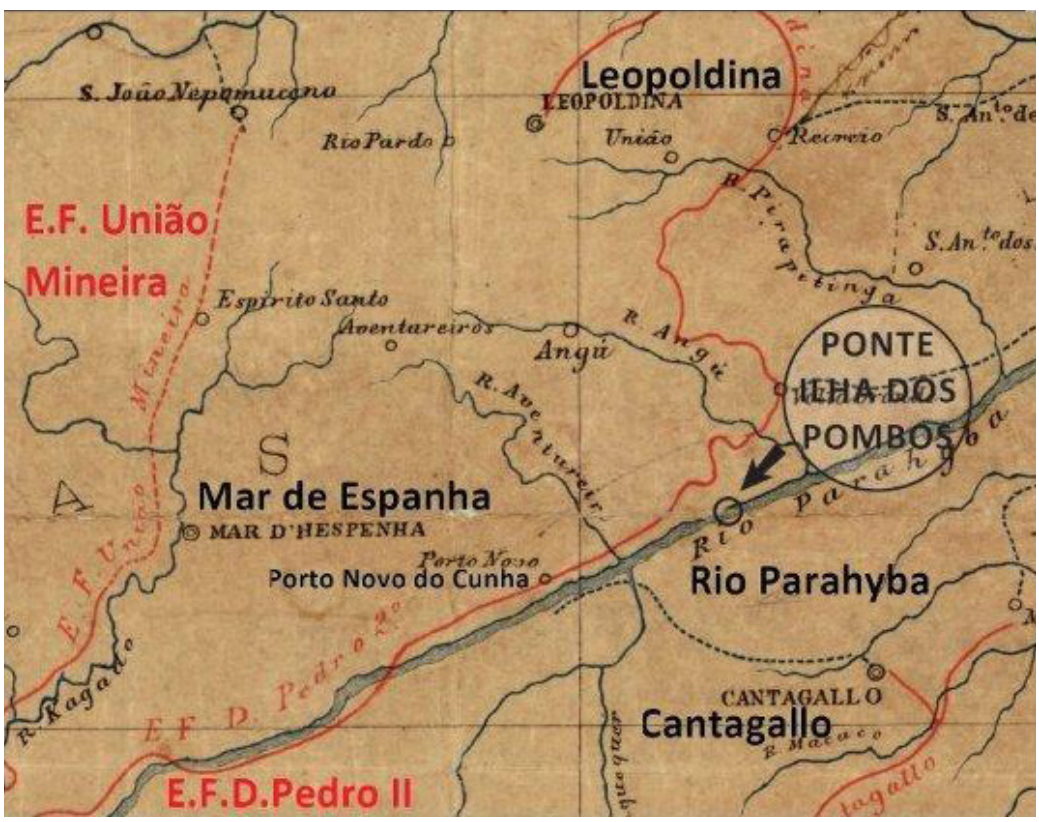

Fonte: Arquivo Público Mineiro, PP-014. 
43

COELHO, Edmundo Campos. As profissões imperiais: Medicina, Engenharia e Advocacia no Rio de Janeiro (1822-1930). São Paulo: Editora Record, 1999. MARINHO, Pedro Eduardo M. de Monteiro. Porta-vozes em uma era de incertezas: o Clube de Engenharia e a concepção de uma inspetoria geral das estradas de ferro. Revista Brasileira de História da Ciência, Rio de Janeiro, v.3, n.2, p.170-183, jul-dez/2010.

44

KLEIN, Hebert. A oferta de muares no Brasil central: o mercado de Sorocaba, 1825-1880. Estudos Econômicos, v.19, n.2, p.356-357, maiago/1989.

45

ELLIS JUNIOR, Alfredo. 0 ciclo do muar. Revista de História, ano I, p.73, jan-mar/1950.

46

KLEIN, Hebert. Op. Cit., p.366.

47

ANDRADE, Rômulo Garcia. Escravidão e

Cafeicultura em Minas Gerais: o caso da Zona da Mata. Revista Brasileira de História. São Paulo, v.11, n.22, p.101, mar-ago/1991.

48

TELLES, Pedro Carlos da Silva. História da Engenharia no Brasil. Rio de Janeiro: Clavero, vol.1, 1994. p.227.

49

SUMMERHILL, William R. Big social savings in a small laggard economy: railroad-led growth in Brazil. The journal of Economic History, v.65, n.1, p.73-76, 2005.
Em maio de 1871, a província de Minas Gerais celebrou o contrato de construção da dita ponte. Para a formulação do dito contrato, atores específicos, mormente engenheiros, atuaram no exame e escolha do local para edificar a ponte, confeccionar a planta e fazer o orçamento. Pode-se afirmar a existência de duas lacunas na historiografia sobre os transportes no Brasil do século XIX: 1) pouco se considera acerca da coexistência entre as modalidades de transporte na década de 1870 e da permanência do uso dos muares numa de região de penetração ferroviária; 2) se desconhece a participação de engenheiros em atividades construtivas do modal não-ferroviário. ${ }^{43} \mathrm{Em}$ relação ao primeiro aspecto, predomina na historiografia a concepção de que um dos efeitos da construção do sistema ferroviário foi a substituição quase imediata dos muares. Segundo Hebert Klein, o advento ferroviário demarcou a substituição das mulas pelas ferrovias. ${ }^{44}$ Para Alfredo Ellis Junior, a década de 1870 culminou no fim do ciclo econômico do muar: "O ciclo do muar nasceu com o ouro, na madrugada, do século XVII e depois de uma vigência de mais de século e meio, morreu em 1875 mais ou menos, com o advento da ferrovia"45 Ambos os autores traçam uma relação direta entre a introdução das ferrovias em uma região agroexportadora e 0 fim do uso de mulas para o transporte, privilegiando uma idéia de ruptura e descontinuidade tecnológica:

\section{A afirmação de que o principal mercado para as mulas era o da exportação de café fica corroborada pelo rápido declínio do mercado de mulas de Sorocaba a partir da chegada das ferrovias originárias do litoral. ${ }^{46}$}

Por outro lado, em seu estudo, Rômulo Andrade indicou a presença, na segunda metade do século XIX, de animais de tração nos inventários post-mortem e sugeriu a permanência dos muares na região da Mata mineira, atuando no fluxo comercial de caráter local nas décadas de 1870 e $1880 .{ }^{47}$

No que tange ao segundo aspecto, a historiografia considera a introdução das ferrovias como ponto nodal para a compreensão da atividade da Engenharia no Brasil, porém sem qualquer menção ou consideração acerca da relevância da participação de engenheiros na construção viária de pontes e estradas. ${ }^{48}$

A expansão ferroviária dinamizou e barateou a circulação de bens e pessoas, permitindo, como se observa na tabela abaixo, a redução do preço do frete e o deslocamento em menor tempo ${ }^{49}$ Portanto, não se deve desconsiderar o impacto das ferroviárias, mormente quando se trata de uma região interiorana com vínculos externos importantes como se evidencia na região da Mata mineira.

Tabela 8 - Valor do Frete (Ferrovias e Muares)

\begin{tabular}{ccc}
\hline Meio de transporte & $\begin{array}{c}\text { Preço de cada arroba por } \\
\text { légua (réis) }\end{array}$ & $\begin{array}{c}\text { Distância regular percorrida por dia } \\
\text { (léguas) }\end{array}$ \\
\hline Muares & $0 \$ 40$ & 3 e 4 léguas \\
\hline Ferrovias & $0 \$ 20$ & 5 léguas \\
\hline
\end{tabular}

Fonte: Arquivo Público Mineiro, SPOP 3-1, caixa 1, doc.05; QUEIROZ, João Ramos de. Ligação da província de São Paulo ao Rio São Francisco. Rio de Janeiro: Typografia do Globo, 1875. p.18-31 (cf. KLEIN, Hebert. A oferta de muares. Estudos Econômicos, São Paulo, v.19, n.2, p.347-372, maio-ago.1989). 
Para a conversão de réis para libra esterlina, utilizamos a cotação mensal da libra esterlina em relação ao réis referente ao mês de abril de 1871 (pence/mil réis $=25,25$ ). Cf. FRANCO, Gustavo $\mathrm{H}$. Barroso. Setor Externo. In: Estatísticas históricas do Brasil: séries econômicas, demográficas e sociais de 1550 a 1988. 2a edição revista. Rio de Janeiro: IBGE, 1990. p.557-598.

Arquivo Público Mineiro, SPOP 3-6, caixa 41, doc.18-44.
No entanto, o avanço ferroviário se realizou sem articulação intermodal (ferrovia-rodovia). A introdução das ferrovias alterou traçados de estradas já projetadas por engenheiros e contribuiu para o decréscimo das rendas geradas pelas Recebedorias fundamentais para o aperfeiçoamento de pontes e estradas.

Em vista dessa perspectiva, compreende-se que a ponte da llha dos Pombos seja um caso emblemático, dada a singularidade do avanço ferroviário na região. A construção da dita ponte somente foi decidida após ser resolvido que os trilhos da Estrada de Ferro D. Pedro II alcançariam a localidade de Porto Novo do Cunha.

As ligações comerciais de diversas localidades de Minas Gerais, mormente com a cidade de Cantagalo, impunham a necessidade de uma ponte cuja construção, apesar do alto valor de 31:231\$000 réis (em torno de 7.800 libras esterlinas), seria justificável visto que a diversidade do fluxo mercantil não seria atendida pelas ferrovias em expansão na região da Mata mineira. 0 engenheiro Bruno Von Sperling enfatizou as relações comerciais dos municípios de Mar de Espanha, Leopoldina, São Paulo do Muriaé, Ponte Nova e Abre Campo com o município cafeicultor de Cantagalo: ${ }^{50}$

[...] não é so a grande exportação do café que vem a questão; existe hoje um comércio muito ativo entre o rico municipio de Cantagalo e a Provincia de Minas Gerais para que concorrem não so os municipios de Mar d'Hespanha, Leopoldina e São Paulo do Muriahe [...] mas sim tambem aqueles mais ao Norte até a Ponte Nova e Abre Campo sendo quasi exclusivamente por ali para onde exporta este ultimo e a respeito de estrada tão mal aquinhoado Distrito. Milhares de arrobas de toucinho, açucar,[...], tecidos, solla e igualmente milhares de cabeças de porcos, gado vacum, bestas bravas e arreiadas atravessão anualmente o Parahyba achando sempre um favorável mercado no Distrito de Cantagalo, entregue exclusivamente, como V.S. bem sabe, a cultura de café. Esta exportação por ali em todo tempo há de continuar por que torna-se mais seguro e lucrativo ao exportador, de que demandar o grande mercado do Rio de Janeiro por via da Estrada de Ferro. E isso está provado, pois o que sustenta ainda hoje as Recebedorias do Porto Novo e Velho do Cunha e da Pirapetinga é este mesmo comercio, pois o café já todo se dirige a estação do Chiador. Em consequência a utilidade e mesmo a necessidade d'uma ponte por aqueles lugares é e será sempre patente, assim como, creio eu, a renda d'esta ponte será suficiente não só para a despesa d'arrecadação como para dar um bom juro do capital empregado, acrescendo, para isso a circunstancia de assim que se abrir a estação do Porto Novo do Cunha e assim que constar que existe uma ponte, único meio seguro e regular de transpor um rio tão caudaloso e largo como é o Parahyba, todos os exportadores das vertentes do Parahyba na Provincia do Rio até a Aldea das Pedras hão de procurar a estrada de Ferro de D. Pedro $2^{\circ}$ e por conseguinte as suas tropas atravessara a ponte, dando assim não so uma renda prospera como $\mathrm{m}^{\mathrm{mo}} \mathrm{um}$ importante lucro á Provincia. ${ }^{51}$

Para a composição do orçamento da ponte da llha dos Pombos participaram três engenheiros, responsáveis pelos valores e os materiais a serem utilizados na obra: o engenheiro Francisco Pereira Passos, Chefe da Secção da Estrada de Ferro D. Pedro II; engenheiro Clemente de Novelleto Spetzler, $1^{\circ}$ ajudante da referida estrada e o engenheiro Bruno Von Sperling, da província de Minas Gerais. 0 primeiro orçamento foi projetado pelos engenheiros da Estrada de Ferro D. Pedro II e logo chegou ao conhecimento do engenheiro provincial Bruno Von Sperling, que tratou de avaliá-lo e apresentar um relatório técnico favorável ao orçamento apresentado pelos engenheiros da Estrada de Ferro D. Pedro II: "O projeto me parece bem concebido, recomenda-se por sua singeleza e oferece toda a segurança (...)" ${ }^{52}$. 
Organograma 1 - Engenheiros e a elaboração do orçamento da ponte sobre o Rio Parahyba

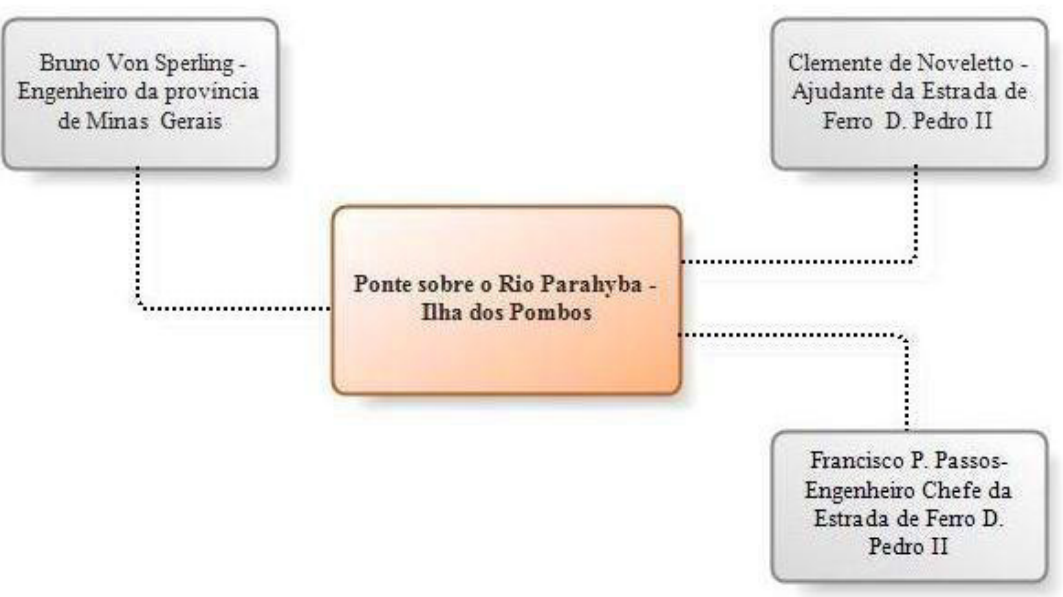

Fonte: Arquivo Público Mineiro, SPOP 3-6, caixa 41, doc.18.

Após a conclusão da obra, em 1873, o empreiteiro José Maria apresentou um requerimento solicitando uma indenização de 13:978\$205 réis, resultante da diferença entre o custo final e o orçamento inicial. 0 requerimento era composto por um parecer, que constava da assinatura de três engenheiros e pretendia justificar o valor acrescido na obra e, portanto, legitimar o pagamento da indenização: João Gomes do Val, engenheiro chefe da Estrada de Ferro Leopoldina, Joaquim Vieira Ferreira, engenheiro da mesma estrada e José Ribeiro da S. Pirajá, engenheiro da Estrada de

Tabela 9 - Orçamento inicial e o custo final da ponte sobre o Rio Paraíba

\begin{tabular}{ccc}
\hline Orçamento inicial & Custo final & Acréscimo ao orçamento inicial \\
\hline $31: 231 \$ 000$ & $45: 209 \$ 205$ & $13: 978 \$ 205$ \\
\hline
\end{tabular}

Fonte: Arquivo Público Mineiro, SPOP 3-6, caixa 41, doc.18.

A fim de obter o pagamento da verba indenizatória, o empreiteiro José Maria apresentou diversos recibos, notas e as folhas mensais dos trabalhadores (nome, ocupação, valor do jornal). Segundo as informações prestadas pelo empreiteiro, temos um número mensal médio de vinte e oito trabalhadores envolvidos na edificação da ponte entre os meses de novembro de 1871 e agosto de 1872.

Compunha ainda a despesa da obra o custo de diversos materiais como, por exemplo, ferro, cimento, cal, verniz, madeira, carvão, assim como os trabalhos de construção: derrubada da mata e aterro. Para a aquisição de parte dos materiais empregados, o empreiteiro estabeleceu relações mercantis com diversos estabelecimentos comerciais na cidade do Rio de Janeiro. Parte do ferro e cimento, aproximadamente $42 \%$ do valor total gasto na compra do referido item, foram adquiridos no Armazém Silva Monteiro \& Cia. As ferragens na loja Monteiro \& Correia e os cabos no estabelecimento Rebello \& Cia. Todas, casas comerciais situadas na cidade do Rio de Janeiro. ${ }^{54}$ 


\begin{tabular}{|c|c|c|}
\hline Despesa & Valor (Réis) & $\%$ \\
\hline Derrubada na margem esquerda do Rio & $48 \$ 000$ & 0.1 \\
\hline Ferragem & $53 \$ 040$ & 0.1 \\
\hline Três Barris de Verniz & $92 \$ 000$ & 0.2 \\
\hline Carvão & $254 \$ 800$ & 0.5 \\
\hline Vinte dúzias de tábuas para andaimes (cada dúzia valor de $0 \$ 15$ ) & $300 \$ 000$ & 0.6 \\
\hline Cabos & $490 \$ 860$ & 1.0 \\
\hline Despesas em viagens ao Rio de Janeiro & $314 \$ 800$ & 0.7 \\
\hline Aterro da ponte & $575 \$ 000$ & 1.3 \\
\hline Vinte e nove dúzias de pranchões para soalho (cada dúzia valor de $0 \$ 36$ ) & $1: 044 \$ 000$ & 2.1 \\
\hline Materiais & $1: 220 \$ 480$ & 2.7 \\
\hline Cal & $1: 330 \$ 000$ & 3.0 \\
\hline Ferro e Cimento & $3: 506 \$ 180$ & 7.8 \\
\hline Madeira & $6: 100 \$ 000$ & 13.4 \\
\hline Carpinteiro & 7:092\$850 & 16.0 \\
\hline Pedreiros* & $24: 007 \$ 675$ & 53.0 \\
\hline Total & $45: 209 \$ 205$ & 100.0 \\
\hline
\end{tabular}

Os jornais pagos permitem situar os artífices numa hierarquia em razão da renda. Deve-se atentar que a ocupação também se entrelaça à faixa etária, a condição social (livre e/ou escravo) e às variáveis demográficas. Porém, as fontes primárias em análise não permitem maiores asserções sobre as idades e a condição social dos artífices: "Entre todas as variáveis que conferem a cada profissão seu nível na hierarquia social, os salários e vencimentos são os mais discriminantes

(...) mas também os mais dificeis a serem avaliados sem erro". HÉLIN, Etienne. Profissão e estatuto social. In: MARCÍLIO, Maria Luiza (org). Demografia Histórica. São Paulo: Livraria Pioneira Editora, 1977. p.194.

56

SILVA, Antonio de Moraes. Diccionario da língua portugueza. $4^{\text {a }}$ edição. Lisboa: Impressão Régia, 1831. p.333.

57

Arquivo Público Mineiro, SPOP 3-6, caixa 41, doc.18-165.
Fonte: Arquivo Público Mineiro, SPOP 3-6, caixa 41, doc.18-11.

${ }^{*}$ ) A denominação pedreiro aparece como algo genérico na documentação. Nesta categoria estão englobadas as seguintes ocupações: Mestre, Contramestre, Canteiro, Cavouqueiro, Servente, Ajudante, Cozinheiro, Ferreiro, Carreiro.

Em conjunto, os artífices representaram $69 \%$ do custo total da obra. ${ }^{55}$ Dentre os trabalhadores, nota-se a superioridade numérica e a constante presença dos artífices denominados canteiros. Este artífice, "official, que lavra pedras de cantaria", ${ }_{1}^{6}$ era responsável por transformar as pedras brutas em pedras retangulares, como ressalta o Engenheiro Bruno Von Sperling:

Os canteiros [...] com o emprego do martello, picão e escopo transformao as pedras brutas á formas retangulares com as faces, leitos e subleitos talhados e faceados [...] torna-se necessario para a qualificação de canteiro muito mais pratica no officio, ganhando por este motivo estes operários jornaes mais altos (...). ${ }^{57}$

Por outro lado, apesar de se encontrarem em termos numéricos inferiores, os artífices de mestre, contramestre e ferreiro apresentavam altos jornais e presença em todos os meses. 
Tabela 11 - Trabalhadores na construção da ponte sobre o Rio Paraíba (nov. de 1871 - ago. de 1872)

\begin{tabular}{|c|c|c|c|c|c|c|c|c|c|c|c|}
\hline \multirow{2}{*}{ Ocupação } & \multirow{2}{*}{ Jornal } & \multicolumn{10}{|c|}{ Número de trabalhadores empregados em cada mês } \\
\hline & & Nov. & Dez. & Jan. & Fev. & Mar. & Abr. & Mai. & Jun. & Jul. & Ago. \\
\hline Mestre & $6 \$ 000$ & 1 & 1 & 1 & 1 & 1 & 1 & 1 & 1 & 1 & 1 \\
\hline Contra Mestre & $3 \$ 800$ & 1 & 1 & 1 & 1 & 1 & 1 & 1 & 1 & 1 & 1 \\
\hline Ferreiro & $4 \$ 000$ & 1 & 1 & 1 & 1 & 1 & 1 & 2 & 1 & 1 & 2 \\
\hline Carpinteiro & $3 \$ 500$ & 2 & 2 & 1 & & & & & & & \\
\hline Canteiro & $3 \$ 500$ & 14 & 16 & 19 & 21 & 21 & 20 & 18 & 21 & 10 & 9 \\
\hline Cavouqueiro & $3 \$ 000$ & 5 & 2 & 3 & 4 & 2 & 4 & 4 & 1 & 1 & 1 \\
\hline Ajudante & $3 \$ 000$ & 1 & 1 & 1 & 1 & 1 & 1 & 2 & 1 & 2 & 1 \\
\hline Carreiro & $2 \$ 500$ & & 2 & & & & & & & 2 & 2 \\
\hline Servente & $2 \$ 500$ & 3 & 1 & 5 & 1 & 2 & 2 & 1 & 2 & & 1 \\
\hline Cozinheiro & $3 \$ 000$ & 1 & 1 & 1 & 1 & 1 & 1 & 1 & 1 & 1 & 1 \\
\hline Total & & 29 & 28 & 33 & 31 & 30 & 31 & 30 & 29 & 19 & 19 \\
\hline
\end{tabular}

Fonte: Arquivo Público Mineiro, SPOP 3-6, caixa 41, doc.18-71, 18-72, 18-76, 18-79, 18-80, 18-87, 18-88, 18-91, 18-93, 18-94, 18-111.

Porém, o Diretor interino das Obras Públicas, o engenheiro Bruno Von Sperling, questionava a validade das despesas apresentadas pelo empreiteiro para o cálculo da indenização, sobretudo as contas relativas aos trabaIhadores empregados na obra e a possibilidade de fraudes contábeis. ${ }^{58}$

Apesar das ressalvas do Diretor interino de Obras Públicas, os relatórios dos engenheiros provinciais Rodrigo Ribeiro e Antonio Horta Barbosa avaliaram que a construção da dita ponte deveria ser aceita. 0 Engenheiro Rodrigo Ribeiro ressaltava que as modificações feitas pelo empreiteiro não afetavam "[...] três principais requisitos de - estabilidade, solidez e durabilidade [...] em boas condições e em estado de ser aceita pela província" ${ }^{49}$. Após os pareceres dos engenheiros, a província de Minas Gerais, através da Lei n. 2323 de julho de 1876, sancionou o pagamento indenizatório ao cidadão José Maria de Souza Passos em vista "[...] dos prejuizos que provou haver sofrido por acréscimo de obras e erros de cálculo na confecção da planta e orçamento da ponte sobre o Parahyba na Ilha dos Pombos (...)".60

Organograma 2 - Engenheiros que elaboraram pareceres acerca da ponte sobre o Rio Paraíba

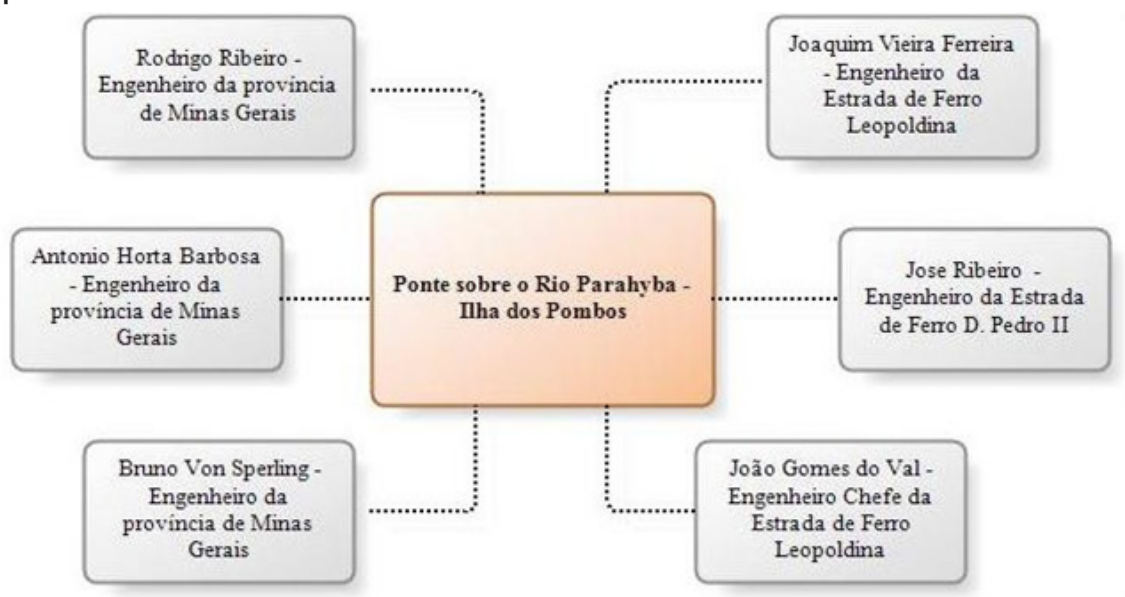

Fonte: Arquivo Público Mineiro, SPOP 3-6, caixa 41, doc.18. 
Em Minas Gerais a expansão ferroviária encontrou na concessão de juros de 7\% ao ano ou subvenção de 9 contos por quilômetro e na isenção de imposto sobre as importações de máquinas e materiais para ferrovias subsidios para o empreendimento ferroviário. Em 1869 a linha férrea D. Pedro II inaugurou o primeiro trecho ferroviário de Minas Gerais entre Entre Rios e Chiador: "As regiões produtores de café eram responsáveis por $80 \%$ desse sistema no final do século XIX. (...) Minas Gerais, em 1880, ainda era relativamente atrasada no transporte ferroviário. Em 1871, os trilhos da Pedro II tinham alcançado Porto Novo, o que permitiu que o café mineiro descesse diretamente para o Porto do Rio de Janeiro. (...) Em 1905 este estado tinha quase 4 mil km de linhas em tráfego. Esta rede tinha tido crescimento de $8,73 \%$ a.a., ligeiramente abaixo da média nacional que havia sido de $8,8 \%$ a.a.". MELO, Hildete Pereira de. Op. Cit., p.342.
A construção da ponte da llha dos Pombos revela-nos o dinamismo do mercado interprovincial e a singularidade de uma modernização esquecida em uma região agroexportadora face à insuficiência da expansão ferroviária em atender fluxos interprovinciais. ${ }^{61}$

A singular presença de engenheiros provinciais (Bruno Von Sperling, Antonio Horta e Rodrigo Ribeiro) e engenheiros ferroviários (José Ribeiro, João Gomes do Val, Francisco Pereira Passos, Clemente Novelleto e Joaquim Vieira) na projeção orçamentária, na confecção de planta e execução de uma ponte mista (madeira e pedra), são expressivos indícios do aperfeiçoamento de um "velho" artefato tecnológico: uma ponte de madeira e pedra.

\section{Considerações finais}

0 arranjo fiscal em prática no Brasil Imperial a partir do Ato Adicional de 1834 tornou inequívoca a necessidade de aperfeiçoamento viário (pontes e estradas) como mecanismo para o aumento da receita das províncias. 0 desejo de aumento da arrecadação provincial, proveniente de tributos cobrados sob a circulação de bens e pessoas, propiciou que os circuitos mercantis estabelecidos entre Minas Gerais e o Rio de Janeiro obtivessem aporte de recursos financeiros e humanos (engenheiros) para a construção da infraestrutura viária na região agroexportadora da Mata mineira.

Apesar da magnitude do fluxo de bens e pessoas entre Minas Gerais e Rio de Janeiro, a existência desta rota mercantil não resultou na difusão e construção da ponte pênsil sobre o Rio Paraíba. A tentativa de implementação da ponte pênsil em território mineiro pelo português Antonio Joaquim Pereira de Carvalho revelou obstáculos diversos: a presença de conflitos entre o Inspetor Geral das Obras Públicas e o português; os interesses privatistas e escusos da Comissão de locais; a recusa da mesma Comissão em designar um local para efetivar a construção da ponte pênsil; a falsa alegação "técnica" do alto custo da obra decorrente do erro de cálculo da largura do Rio Paraíba.

Construir pontes e estradas exigia exames prévios da configuração do terreno e do movimento do comércio. Se, por um lado, o fracasso da ponte pênsil denota a incapacidade de modernização através do sistema de patente de 1830, por outro, o êxito da ponte de madeira e pedra da Ilha dos Pombos indica tanto o aperfeiçoamento técnico em virtude da presença de diversos engenheiros quanto a combinação de iniciativas do mercado (exportador de café e abastecedor de gêneros alimentícios) e do Estado no processo de modernização da infraestrutura viária.

A infraestrutura ferroviária, em construção na região da Mata, apresentou limites no que refere à capacidade das linhas férreas em atender a diversidade dos circuitos mercantis, que se direcionavam de Minas Gerais em direção à província do Rio de Janeiro. A diversificada circulação agropecuária mercantil oriunda de Minas Gerais (tecido, açúcar, toucinho, porcos, muares, sola e gado vacum), que se deslocava em direção à cidade de Cantagalo, exigiu o aperfeiçoamento das edificações viárias (pontes e estradas). A singularidade da ponte da Ilha dos Pombos orçada em, aproximadamente, 7.800 mil libras esterlinas, edificada com a finalidade de integrar o circuito mercantil inter-regional entre as diversas localidades da província de Minas Gerais e a cidade cafeicultora de Cantagalo, revela um largo espaço para o desenvolvimento de atividades econômicas não vinculadas, diretamente, à grande lavou- 
ra. A construção de pontes e estradas ensejou o desenvolvimento das atividades de diversos artífices e, portanto, da vigência de um mercado de trabalho, bem como uma ampliação das atividades econômicas do mercado interno.

A região da Mata mineira comportou uma modernização delineada tanto pelo incremento da produção cafeeira e dos laços desta atividade com o mercado internacional quanto pela presença de um mercado intermediário, inter-regional, entrelaçado ao setor cafeeiro, que oferecia aos produtores de gêneros agrícolas e pecuários de Minas Gerais um mercado lucrativo na localidade fluminense de Cantagalo. A construção da infraestrutura viária para integrar esses circuitos mercantis internos e externos dependeu de interesses fiscais, políticos e econômicos e, sobretudo, de recursos humanos (engenheiros e artífices) para o empreendimento construtivo de pontes e estradas. 